\title{
A rhinopristiform sawfish (genus Pristis) from the middle Eocene (Lutetian) of southern Peru and its regional implications
}

\author{
Alberto Collareta ${ }^{1,2}$ \\ Luz Tejada-Medina ${ }^{3,4}$ \\ César Chacaltana-Budiel ${ }^{3,5}$ \\ Walter LANDINI ${ }^{1,6}$ \\ Alí Altamirano-SierRa 7,8 \\ Mario URBINA-SCHMITT ${ }^{7,9}$ \\ Giovanni BIANUCCI ${ }^{1,10}$
}

\begin{abstract}
Modern sawfishes (Rhinopristiformes: Pristidae) are circumglobally distributed in warm waters and are common in proximal marine and even freshwater habitats. The fossil record of modern pristid genera (i.e., Pristis and Anoxypristis) dates back to the early Eocene and is mostly represented by isolated rostral spines and oral teeth, with phosphatised rostra representing exceptional occurrences. Here, we report on a partial pristid rostrum, exhibiting several articulated rostral spines, from middle Eocene strata of the Paracas Formation (Yumaque Member) exposed in the southern Peruvian East Pisco Basin. This finely preserved specimen shows anatomical structures that are unlikely to leave a fossil record, e.g., the paracentral grooves that extend along the ventral surface of the rostrum. Based on the morphology of the rostral spines, this fossil sawfish is here identified as belonging to Pristis. To our knowledge, this discovery represents the geologically oldest known occurrence of Pristidae from the Pacific Coast of South America. Although the fossil record of pristids from the East Pisco Basin spans from the middle Eocene to the late Miocene, sawfishes are no longer present in the modern cool, upwelling-influenced coastal waters of southern Peru. Given the ecological preferences of the extant members of Pristis, the occurrence of this genus in the Paracas deposits suggests that middle Eocene nearshore waters in southern Peru were warmer than today. The eventual disappearance of pristids from the coastal waters off southern Peru might be interpreted as reflecting the late Cenozoic trend of strengthening of the Humboldt Current.
\end{abstract}

\section{Key-words:}

- East Pisco Basin;

- Elasmobranchii;

- exceptional preservation;

- Humboldt Current System;

- palaeobiogeography;

- palaeoclimatology;

- palaeoenvironments;

- Paracas Formation (Yumaque Member)

Citation: Collareta A., Tejada-Medina L., Chacaltana-Budiel C., Landini W., Altamirano-Sierra A., UrBINA-SCHMITT M. \& BIANUCCI G. (2020).- A rhinopristiform sawfish (genus Pristis) from the middle Eocene (Lutetian) of southern Peru and its regional implications.- Carnets Geol., Madrid, vol. 20, no. 5, p. 91-105.

${ }^{1}$ Dipartimento di Scienze della Terra, Università di Pisa, via Santa Maria 53, 56126 Pisa (Italy)

2 alberto.collareta@unipi.it

3 Instituto Geológico Minero y Metalúrgico (INGEMMET), Avenida Canadá 1470, San Borja, Lima 41 (Peru)

4 Itejada@ingemmet.gob.pe

${ }^{5}$ cchacaltana@ingemmet.gob.pe

6 walter.landini@unipi.it

7 Departamento de Paleontología de Vertebrados, Museo de Historia Natural de la Universidad Nacional Mayor de San Marcos, Avenida Arenales 1256, Jesús María, Lima 14 (Peru)

8 eraexcusa@yahoo.es

9 mariourbina01@hotmail.com

10 giovanni.bianucci@unipi.it

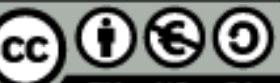


Résumé : Un poisson-scie rhinopristiforme (genre Pristis) de l'Éocène moyen (Lutétien) du Pérou méridional et ses implications régionales.- Les poissons-scies modernes (Rhinopristiformes : Pristidae) présentent une distribution globale dans les eaux chaudes; ils sont fréquents dans les habitats marins proximaux et même en eaux douces. Le registre fossile des genres modernes des Pristidés (i.e., Pristis et Anoxypristis) remonte à l'Eocène inférieur et est principalement représenté par des épines rostrales isolées et dents orales, ainsi que des rostres phosphatés représentant des événements exceptionnels. Nous rapportons ici un rostre partiel de Pristidae, présentant plusieurs épines rostrales articulées, provenant des couches de l'Éocène moyen de la Formation Paracas (Membre Yumaque) exposées dans la partie orientale du Bassin de Pisco au sud du Pérou. Ce spécimen très bien conservé permet l'observation de structures anatomiques qui sont difficilement fossilisables, par exemple les sillons paracentraux qui s'étirent le long de la face ventrale du rostrum. En se basant sur la morphologie des épines rostrales, ce poisson-scie fossile est identifié ici comme appartenant à Pristis. À notre connaissance, cette découverte représente la plus ancienne occurrence géologique connue de Pristidae le long des côtes pacifiques de l'Amérique du Sud. Bien que le registre fossile des Pristidés dans la partie orientale du Bassin de Pisco s'étende de l'Éocène moyen au Miocène supérieur, les poissons-scie ne sont plus actuellement présents dans les eaux côtières du sud du Pérou, eaux fraîches en raison de remontées d'eaux profondes. À la lumière des préférences écologiques des membres actuels du genre Pristis, la présence de ce genre dans la Formation Paracas suggère des températures de l'eau de mer plus élevées qu'actuellement dans les environnements littoraux du sud du Pérou au cours de l'Éocène moyen. La disparition finale des Pristidés des eaux côtières du sud du Pérou pourrait être interprétée comme reflétant la tendance au renforcement du courant de Humboldt au Cénozoïque supérieur.

\section{Mots-clefs :}

- partie orientale du Bassin Pisco :

- Elasmobranchii ;

- conservation exceptionnelle :

- Système du Courant de Humboldt ;

- paléobiogéographie

- paléoclimatologie ;

- paléoenvironnements

- Formation Paracas (Membre de Yumaque)

\section{Introduction}

Among extant cartilaginous fishes, members of the family Pristidae are large-sized, shark-shaped rays characterised by an elongated, dorsoventrally flattened rostrum whose lateral margins bear lancet-like, continuously growing, highly modified placoid scales (e.g., CAPPETTA, 2012; WeLTEN et al., 2015). These dermal elements were described under several different terms, including "rostral teeth" and "rostral spines". Following CarRillo-Briceño et al. (2015) and CollaRETA et al. (2017a), the latter term is here preferred. Pristids are active predators that use their saw-like rostrum to uncover infaunal food items, immobilise potential prey, and stun or slash small fish and invertebrates (WUERINGER et al., 2009, and references therein); as such, they are popularly known as "sawfishes". Extant pristids are classified into two genera: Pristis Linck, 1790, which includes four living species, and Anoxypristis WHITE \& MOY-THOMAS, 1941, for which a single living species is known (LAST et al., 2016; WEIGMANN, 2016). These aquatic representatives of the charismatic megafauna (here intended as large-sized animal species whose widespread appeal or symbolic value is seen as pivotal for attracting popular attention on conservation goals and policies; see e.g. DuCARME et al., 2013) are circumglobally distributed in warm waters and are common in proximal marine and even brackish and freshwater habitats (e.g., WUERINGER et al., 2009; Dulvy et al., 2014). The fossil record of modern pristid genera dates back to the early Eocene and is mostly represented by isolated rostral spines and subordinate oral teeth (CAPPETTA, 2006, 2012; but see also CASE, 1994, for a re- cord of Pristis from possibly upper Palaeocene strata of the Tuscahoma Formation of Mississippi, USA); in addition, exceptional occurrences of phosphatised rostra have also been reported from a few localities worldwide (e.g., VIGLIAROLO, 1891; LERICHE, 1905; ZBYSZEWSKI, 1947; CASIER, 1949; Farrés, 2003; CiCIMURRI, 2007; CARrillo-BriceÑo et al., 2015).

Decades of research on the celebrated fossil content of the East Pisco Basin of southern Peru has produced numerous noteworthy palaeontological papers dealing with various groups of aquatic vertebrates, including marine mammals (e.g., MUIZON, 1988; BRAND et al., 2004; ESPERANTE et al., 2008; LAMBERT et al., 2010, 2017, 2019; BIANUCCI et al., 2010, 2016a, 2016b) and seabirds (e.g., ClaRKE et al., 2007, 2010). In turn, the current knowledge of the fossil history of cartilaginous and bony fishes from this region is still scanty. In particular, for a long time, contributions dealing with the record of the cartilaginous fishes have been mostly limited to plain faunal lists (e.g., Muizon \& DeVRies, 1985; Bianucci et al., 2010). However, recent investigations have focused on exceptionally preserved specimens (Collareta et al., 2017c), rare and elusive taxa (SHIMADA et al., 2017), and outstandingly productive tooth-bearing horizons from a handful of Miocene localities (e.g., BIANUCCI et al., 2018; LANDINI et al., 2017a, 2017b, 2019). These studies provide a more comprehensive picture of the Neogene shark and ray assemblages from the basin infill.

In the present paper, we report on a partial pristid rostrum that exhibits several articulated rostral spines, from middle Eocene strata of the Paracas Formation exposed in the vicinity of the Zamaca locality, in the eastern sector of the East 
Pisco Basin. This finely preserved specimen is here figured, described, and referred to the extant genus Pristis. The palaeobiogeographic, palaeoenvironmental, and palaeoclimatic implications of this remarkable fossil are then briefly discussed.

\section{Geological framework}

The East Pisco Basin is a northwest-southeast elongated Andean forearc basin that extends along a desertic coastal plain between the towns of Pisco and Nazca (Ica Region, southern Peru). It is located just landward of where the aseismic Nazca Ridge impinges on the Peru-Chile trench (PIlger, 1981; HSU, 1992; MACharé \& ORTLIEB, 1992; HAMPEL, 2004) (Fig. 1.A). This basin is filled with a Cenozoic sedimentary succession that comprises, in ascending stratigraphic order, the Eocene Caballas and Paracas formations, the Oligo-Miocene Chilcatay Formation, and the MioPliocene Pisco Formation (DUNBAR et al., 1990; DeVRIES, 1998, 2017; Di Celma et al., 2016) (Fig. 1.B). These sedimentary units are lithologically complex and are bounded by regionally extensive unconformities marked by pavements of pebbleto boulder-sized igneous clasts. The unconformities reflect periods of subaerial exposure and document major breaks of the sedimentary history of the East Pisco basin; moreover, intraformational unconformities are also present (DEVRIES, 1998; Di CeLma et al., 2017, 2018a). Therefore, following to the nomenclatural approach proposed by the NACSN (2005), the aforementioned unconformity-bounded formations might rather be regarded as alloformations (Di CELMA et al., 2017).

The sawfish fossil reported here was found in deposits belonging to the middle to upper Eocene Paracas Formation (following the nomenclatural revision of DeVRIES, 2017) (Fig. 1.B). Similar to the transgressive sequences that comprise the geologically younger Chilcatay and Pisco formations (e.g., Di CELMA et al., 2017, 2018a; COLETTI et al., 2018; DeVRIES \& JUD, 2018), the Paracas Formation is comprised of a coarse-grained lower portion (i.e., the Los Choros Member, consisting of conglomerates and mixed siliciclastic-bioclastic sandstones characterised by abundant tests of large benthic foraminifera) that is overlain by a package of finer sediments (i.e., the Yumaque Member, consisting of silty sandstones and siltstones that feature a rich planktic assemblage) (RIVERA, 1957; TSUCHI et al., 1988; DunBar et al., 1990; DeVRIES, 1998, 2017; DeVRIES et al., 2006; LEÓN et al., 2008; UHEN et al., 2011; ColETtT et al., 2019) (Fig. 1.B). Note that a different stratigraphic scheme considers the Paracas Group as comprised of the Los Choros and Yumaque formations (e.g., DÁvILA, 1989; DUNBAR et al., 1990; DEVRIES, 1998; LEón et al., 2008), which is the official position of the Peruvian Geological Survey (Instituto Geológico Minero y Metalúrgico, hereinafter referred to as the INGEMMET). The chondrichthyan specimen described herein comes from the basal strata of the Yumaque Member exposed in the vicinity of the Zamaca locality, along the eastern side of the lower Ica valley (geographic coordinates of the collection site: $14^{\circ}$ 38'27.1" S, 75035'46.4" W) Fig. 1.C). In the same area, ca. $6 \mathrm{~km}$ WSW of the collection site, the depositional age of the lower Yumaque beds has been recently reconstructed as close to $42.37 \mathrm{Ma}$ (i.e., Lutetian Stage) by means of calcareous nannoplankton biostratigraphy (COLETTI et al., 2019; Fig. 1.C). This age estimate is here projected to the fossiliferous horizon where our sawfish specimen was found. Previous investigations on the sedimentological characteristics of nearby outcrops concur in indicating an inshore, inner shelf depositional palaeoenvironment situated below wave base (e.g., DUNBAR et al., 1990; UHEN et al., 2011).

Marine vertebrates from the Paracas Formation include the holotype of the early branching penguin Perudyptes devriesi CLARKE et al., 2007, and the holotypes of four archaic cetaceans, i.e., the basilosaurids Supayacetus muizoni UHEN et al., 2011, and Ocucajea picklingi UHEN et al., 2011, the early diverging mysticete Mystacodon selenensis LAMBERT et al., 2017, and the recently described protocetid Peregocetus pacificus LAMBERT et al., 2019.

\section{Systematic paleontology}

\section{Class CHONDRICHTHYES HUXLEY, 1880 Subclass ELASMOBRANCHII BONAPARTE, 1838 \\ Infraclass NEOSELACHII COMPAGNO, 1977 \\ Superorder BATOMORPHII CAPPETTA, 1980 \\ Order RHINOPRISTIFORMES NAYLOR et al., 2012 \\ Family PRISTIDAE BONAPARTE, 1838 \\ Genus Pristis LINCK, 1790 \\ Pristis sp.}

Figs. 2.A-B, 3.A-B, 4.A-E

Material and repository. CPI-7937, an incomplete rostrum, partially entombed in the surrounding siltstone and featuring at least 50 associated rostral spines (no oral teeth appear to cooccur with the specimen). 'CPI' is the acronym for 'Collección Paleontológica del INGEMMET' (=INGEMMET palaeontological collection), housed in Lima, Peru, where CPI-7937 is permanently kept.

Occurrence. Middle Eocene siltstones exposed in the Zamaca area, Ica Province, southern coast of Peru; GPS geographic coordinates: $1^{\circ} 38^{\prime} 27.1^{\prime \prime} \mathrm{S}, 75^{\circ} 35^{\prime} 46.4^{\prime \prime} \mathrm{W}$ (Fig. 1C). The sediment embedding the sawfish specimen belongs to the basal strata of the Yumaque Member of the Paracas Formation, whose deposition in the vicinity of the study site has been referred to the late Lutetian (see the geological framework for more details).

Rostral cartilage. CPI-7937 is preserved in two distinct blocks of siltstones. The main block (Fig. 2) enables the observation of the $425-\mathrm{mm}$ - 
long anterior-most portion of the rostrum, exposed in ventral view, based on the bending direction of the rostral spines (see description below) and still partly embedded in a silty matrix. The main block also preserves 34 rostral spines, 31 of which are still articulated with the rostral cartilage. The second block consists of tens of morphologically uninformative fragments of rostral cartilage with associated shreds of entombing sediment that are distributed on a 485-mm-long, 175-mm-wide area; moreover, at least 16 disarticulated, partly fragmentary rostral spines are also present. By comparing the reconstructed length of the rostrum (totalling ca. $90 \mathrm{~mm}$ ) with the corresponding dimension in extant pristids (e.g., Seitz \& Hoover, 2017, tab. 1), an adult or late juvenile ontogenetic stage is suggested for CPI-7937.

The portion of rostrum preserved in the main block (Fig. 2) is almost complete and dorsoventrally flattened, being ca. $12 \mathrm{~mm}$ thick along its entire length. Diagenetic compaction resulted in exaggerating the degree of dorsoventral flattening of the rostrum; indeed, the transverse section of the rostrum, which can be observed at the posterior end of the main block, shows that the internal rostral ducts (WUERINGER et al., 2009, and references therein) have collapsed, so that no obvious cavities appear within the rostral cartilage. The rostrum gradually tapers towards its anterior-most tip, which appears to be almost complete. The transverse width of the rostral cartilage varies between ca. $60 \mathrm{~mm}$ (at the anterior end of the rostrum) and ca. $100 \mathrm{~mm}$ (at the posterior termination of the preserved portion of the rostrum). The ventral surface of the rostrum is gently convex to almost flat transversely and bears two distinct grooves trending the entire length of the preserved portion of the rostrum (Fig. 2). Each groove is just lateral to the midline (i.e., paracentral sensu MILLER, 1974) and they are parallel with the lateral margins of the rostrum. In living sawfishes, the paracentral grooves [sensu CICIMURRI (2007), not to be confused with the 'ducts with ophthalmic \& buccal nerves \& rostral artery' of WUERINGER et al. (2009: Fig 4), which in turn coincide with the 'paracentral canals' of CicIMURRI (2007)] that are found on the dorsal and ventral surfaces of the rostrum host blood vessels (i.e., veins; MILLER, 1974). The distance between the paracentral grooves changes gradually from $5.5 \mathrm{~mm}$, measured at the anterior termination of the rostrum, to $14.5 \mathrm{~mm}$ (measured at the posterior end of the preserved portion of the rostrum). Lateral to the paracentral grooves, a series of rectangular cartilage projections emanate from the main body of the rostrum, and the edges of these form the alveoli where the rostral spines are located (Figs. 2,
3.A). All the preserved alveoli still host the corresponding rostral spines, so that each side of the rostrum exhibits 17 rostral spines (see description below). The alveoli of the right and left sides are slightly staggered, rather than directly opposing each other, the extent of unalignment changing significantly along the length of the preserved portion of the rostrum. The spacing between adjacent alveoli, measured at the base of the free portions of the rostral spines (i.e., along the lateral margin of the rostrum), varies between 12-13 $\mathrm{mm}$ (close to the tip of the snout) and $18-19 \mathrm{~mm}$ (at the posterior end of the preserved portion of the rostrum). The second block of cartilage is not informative in terms of rostral cartilage morphology.

Similar to some of the fossilised sawfish rostra described by LERICHE (1905), CASIER (1949), CICIMURRI (2007), and CARRILLO-BRICEÑo et al. (2015), the external surface of CPI-7937 locally displays a fibrous texture. Some fragments of rostral cartilage from the second block (e.g., Fig. 3.B) display the preservation of the individual tesserae that, in chondrichthyan fishes, form the coat of prismatic cartilage surrounding the external surface of the rostrum [see e.g. CicIMURRI (2007) and CARRILLO-BRICEÑo et al. $(2015,2019)$ for a reference on the prismatic cartilage of sawfishes]. These tesserae are rounded-polygonal to almost star-shaped and have a mean diameter of $c a$. 0.7-0.8 $\mathrm{mm}$. More than one layer of prismatic cartilage seems to be present. As highlighted elsewhere (WUERINGER et al., 2011, and references therein), in extant sawfishes, the ampullae of LoRENZINI pass the rostral cartilage through hollow tubules that might get preserved in fossilised rostra. Differing from what was observed by CARRILLO-BRICEÑo et al. (2015) for some phosphatised rostra from the Neogene of Venezuela, however, no trace of the ampullae of LORENZINI could be detected along the external surface of CPI-7937.

Rostral spines. All the preserved rostral spines (Figs. 2.A, 3.A, 4) are rather thick dorsoventrally, moderately elongated mediolaterally, and slightly curved ventrally, with convex anterior and sub-straight posterior margins. As a result of functional wear, the distal parts of the rostral spines are thinner than the proximal ones. In the bestpreserved rostral spines, the anterior margin is regularly rounded, whereas the posterior margin invariantly bears a rather deep mediolateral groove, so that its transverse sections would appear as C-shaped (i.e., concave backwards) (Figs. 3.A, 4.B, 4.D). However, this posterior furrow is only partly developed, carving indeed only the distal halves of the rostral spines of CPI-7937 - a condition that recalls that observed in the extant species Pristis clavata GARMAN, 1906 (FARIA et al., 2013; WHITTY et al., 2014). The dorsal and ven-

Figure 1: Geographical and stratigraphic background of the collection site of the fossil sawfish specimen CPI7937. A) Location of the southern Peruvian East Pisco Basin along the Pacific Coasts of South America. B) Schematic stratigraphic log of the East Pisco Basin sedimentary succession. C) Close-up of the Zamaca area (Google Earth image, (c) 2018 DigitalGlobe). The smaller star indicates the location of the stratigraphic section studied by COLETTI et al. (2019); the larger star indicates the collection site of CPI-7937. 

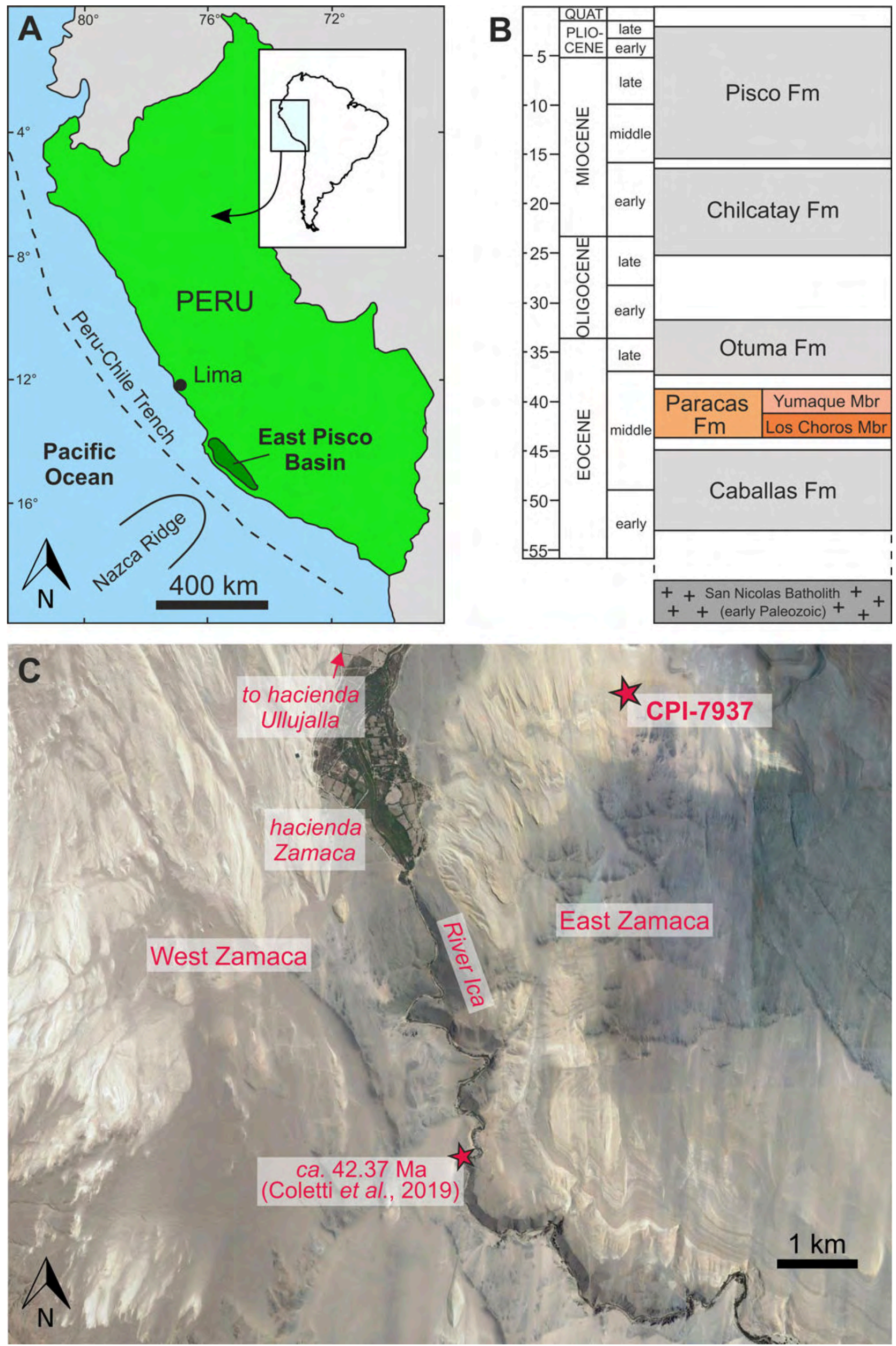

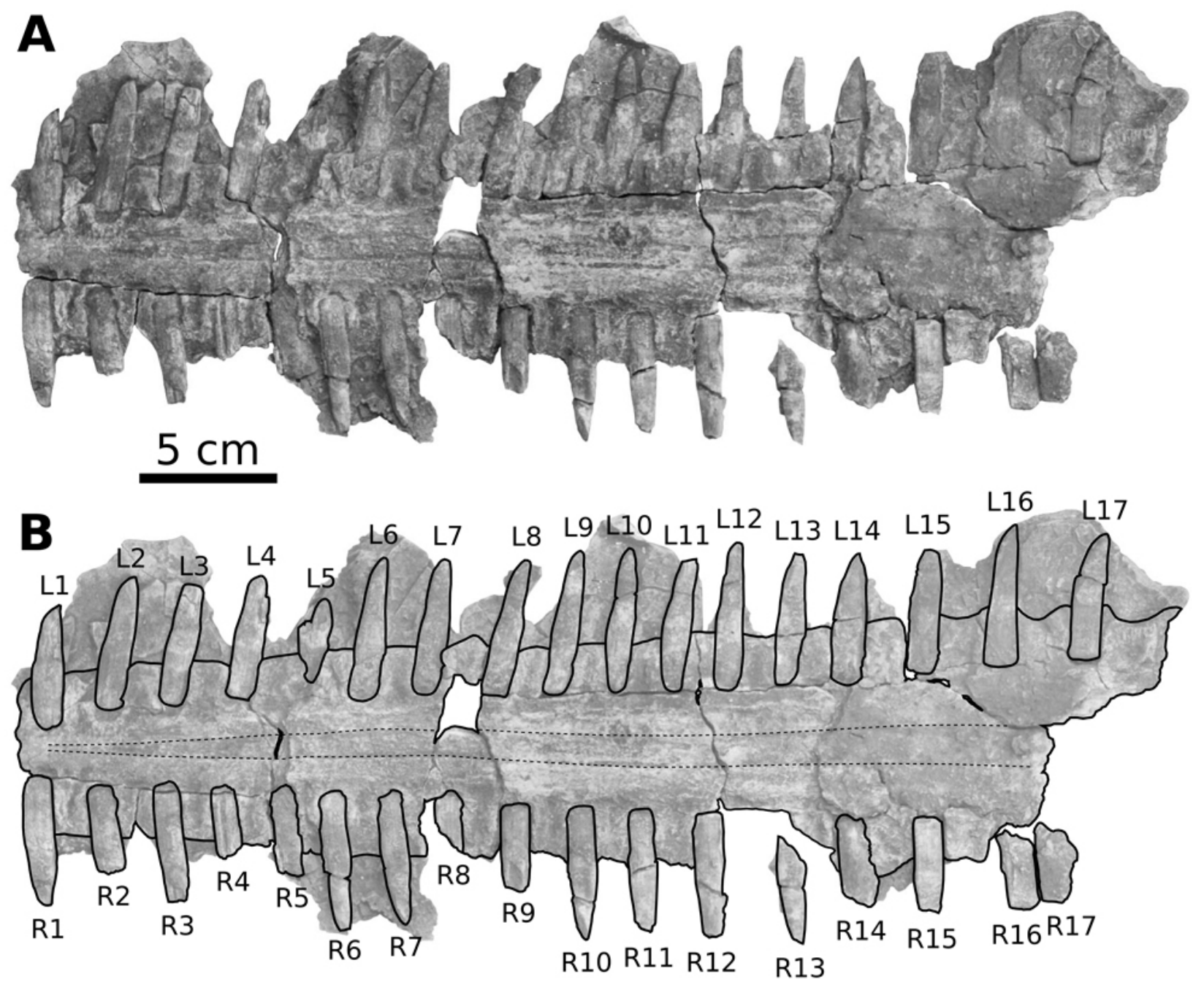

Figure 2: CPI-7937, partial rostrum of Pristis sp. from the Paracas Formation of southern Peru. A) The well-preserved anterior portion of the rostrum, preserving 34 associated rostral spines, in ventral view. B) Corresponding line drawing. Labels L1 to L17 refer to the left row of rostral spines; labels R1 to R17 refer to the right row of rostral spines. The dashed lines indicate the trend of the paracentral grooves (sensu CICIMURRI, 2007) that, in extant pristids, contain veins.

tral surfaces of the rostral spines (Fig. 4.A, 4.C) are gently ornamented by weak, sub-straight radial striae, especially in their basal halves, and show no trace of transversely oriented growth folds. As typical of pristid rostral spines, the proximal parasagittal surface exhibits a porous texture that originates by the presence of a plethora of very small-sized nutrient foramina (HERMAN et al., 1997; MARSILI, 2006) (Fig. 4.E). Differing from other fossil (e.g., CollareTA et al., 2017b) and extant (e.g., NevatTe et al., 2017) rostral spines of sawfish, no obliquely-oriented shallow incisions that might evoke the abrasive action of water laden with sediment flowing at the sides of the rostrum could be detected on the rostra spines of CPI-7937.

From the tip of the snout backwards, the right rostral spines preserved in the main block are here indicated as R1 (the anterior-most one) to R17 (the $17^{\text {th }}$ one); similarly, the left rostral spines are indicated as L1 to L17. Considering the complete rostral spines only, their mediolateral length varies between $46 \mathrm{~mm}$ (in L15) and $55.5 \mathrm{~mm}$ (in L9); overall, no clear trends in rostral spine length are observed moving from the tip of the snout backwards. Similarly, the values of maximum anteroposterior width of these rostral spi- nes are quite invariant, ranging between $10 \mathrm{~mm}$ to $12 \mathrm{~mm}$, whereas their values of maximum dorsoventral thickness equal about one-seventh of the corresponding values of mediolateral length. Whereas the medial halves of the anterior-most rostral spines are located medial to the lateral margins of the rostrum, only about one-third of the total mediolateral length of the rostral spines R15 to R17 and L15 to L17 is located in the corresponding alveoli (Fig. 2). Considering that 17 rostral spines are present on each side of the portion of rostrum preserved in the main block, and 16 additional rostral spines are preserved in the second block, a minimum rostral spine count (i.e., number of spines on each side of the rostrum) of 25 can be reconstructed for CPI-7937. Such an estimate is consistent with the values observed in most extant pristids (Table 1), but distinguishes CPI-7937 from Pristis pristis (LINNAEUS, 1758), here regarded as including also Pristis 'microdon' LATHAM, 1794, and Pristis 'perotteti' Müller \& HeNLE, 1841 (Faria et al., 2013), which exhibits smaller rostral spine counts (WHITTY et al., 2014: tab. 1; LANGE et al., 2015: tab. 1; SEITZ \& HoOver, 2017: tab. 1). 

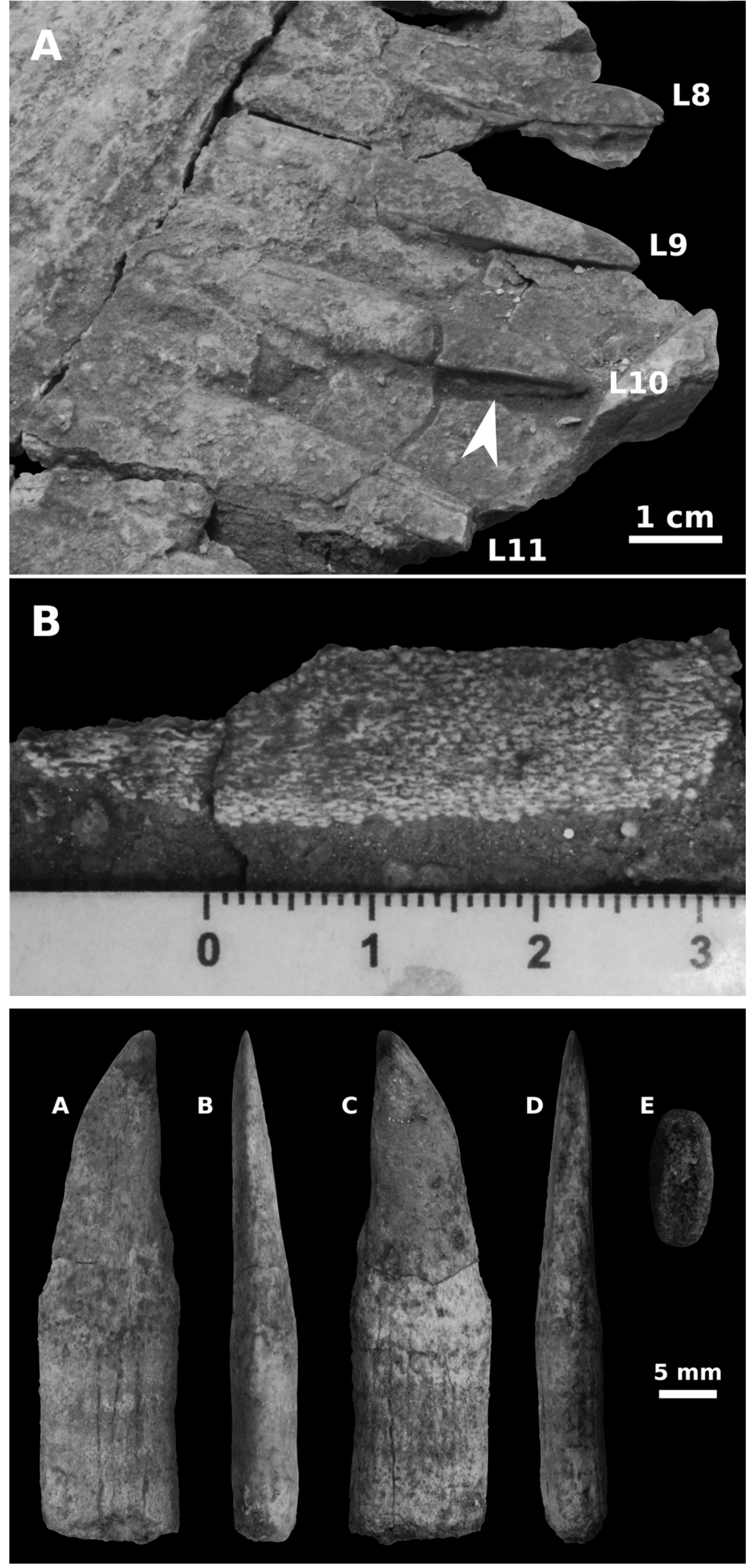

Figure 3: Details of CPI7937, partial rostrum of Pristis sp. from the Paracas Formation of southern Peru. A) Left posterolateral view of the ventral part of rostrum that hosts the rostral spines L8 to L11. The arrowhead indicates the distinctly grooved posterior margin of L10. B) Fragment of fossilised cartilage displaying the individual tesserae that, in chondrichthyan fishes, form the coat of prismatic cartilage that surrounds the external surface of the rostrum. Note that the tessellated structure of the cartilage is seemingly slightly obliterated by an overlying patina of consolidant that could not be removed before taking the photograph.

Figure 4: Close-up of a detached right rostral spine (position unknow but posterior to R17) belonging to CPI-7937, partial rostrum of Pristis sp. from the Paracas Formation of southern Peru. A) Dorsal view. B) Anterior view. C) Ventral view. D) Posterior view. E) Mesial view. Note the worn-down aspect of the lateral half of the rostral spine (panels $B$ and $D$ ) and the presence of an only partially developed groove running along its posterior margin (panel D). Measurements of the figured rostral spine are the following: maximum dorsoventral thickness - $6.5 \mathrm{~mm}$; maximum anteroposterior width $11.5 \mathrm{~mm}$; mediolateral length $-42.5 \mathrm{~mm}$. 
Table 1: Rostral spine count for CPI-7937, the partial rostrum of Pristis sp. described herein, compared with extant and extinct pristid species. The three Venezuelan specimens (AMU-CURS-023, AMU-CURS-235, and AMUCURS-237) come from the middle to upper Miocene Urumaco Formation and have been described in detail by CARRILLO-BRICEÑo et al. (2015). Data from FARRÉS (2003), CARRILlo-BRICEÑo et al. (2015: tab. 1), and the present work.

\begin{tabular}{|l|l|}
\hline Anoxypristis cuspidata (living species) & $16-33$ \\
\hline Anoxypristis osonensis (Eocene, Spain) & 21 \\
\hline Pristis pristis (living species) & $14-24$ \\
\hline Pristis clavata (living species) & $18-27$ \\
\hline Pristis zijsron (living species) & $23-37$ \\
\hline Pristis pectinata (living species) & $20-30$ \\
\hline Pristis atlanticus (Miocene, Portugal) & $\sim 20$ \\
\hline Pristis sp. (AMU-CURS-023: Miocene, Venezuela) & $23 / 24$ \\
\hline Pristis sp. (AMU-CURS-235: Miocene, Venezuela) & 23 \\
\hline Pristis sp. (AMU-CURS-237: Miocene, Venezuela) & $>20$ \\
\hline Pristis sp. (CPI-7937: Eocene, Peru) & $\mathbf{2 2 5}$
\end{tabular}

Systematic identification. Based on the presence of grooves along the posterior margins of the best-preserved rostral spines, CPI-7937 is unambiguously attributed to the genus Pristis (e.g., BOURDON, 1999; COMPAGNO \& LAST, 1999; WUeringer et al., 2009; CAPPETTA, 2012; WelTEN et al., 2015; CAPPETTA \& CASE, 2016). An unambiguous species-level determination of CPI-7937 would need a detailed revision of several extinct nominal species currently attributed to the genus Pristis (at least 29, according to CAPPETTA \& CASE, 2016), which is beyond the scope of the present paper. Interestingly, however, CPI-7937 clearly differs from the widespread Eocene species Pristis lathami GALEOTTI, 1837 (a possible wastebasket taxon; CAPPETTA \& CASE, 2016) by exhibiting relatively stout rostral spines, whose posterior margins bear only partially developed grooves.

Remarks on the preservation state. CPI7937 displays a high degree of preservation. As such, it represents a significant addition to the long list of remarkably preserved vertebrate fossils from the East Pisco Basin, which include articulated skeletons of sharks (Collareta et al., 2017c), phosphatised baleen plates and bristles of mysticete whales (BRAND et al., 2004; ESPERANTE et al., 2008, 2015; GIONCADA et al., 2016; MARX et al., 2017), stomach contents and regurgitations of cetaceans (Collareta et al., 2015, LAMBERT et al., 2015), and even seabird feathers that preserve colour-imparting melanosome morphologies (CLARKE et al., 2010). In the well-studied upper Miocene portion of the Pisco Formation, recent research has shown that many finely preserved fossil vertebrates occur in dolomite concretions, which seem to have formed very early during diagenesis (e.g., GARIBOLDI et al., 2015; GIONCADA et al., 2016, 2018a). In rarer cases, finely preserved vertebrate specimens appear to be enclosed in an apatite-rich volume of sediment delimited by an evident manganiferous boundary, which might also reflect precipitation of early diagenetic minerals around the skeleton (GIONCADA et al., 2018b). The silty sediment that entombs the Zamaca fossil sawfish, however, does not ap- pear to have been modified by early diagenetic cementation, at least macroscopically. This observation allows for associating CPI-7937 with a small-sized mysticete specimen, exhibiting strongly mineralised (i.e., phosphatised) baleen plates, from silty deposits of the Pisco Formation exposed at Cerro Ballena (MARX et al., 2017). In that case, strong mineralisation of the keratinous baleen material was likely made possible thanks to the retention of a relatively permeable, unconsolidated sediment through the first phases of diagenesis, which ultimately allowed the phosphatisation processes to protract for a long time (MARX et al., 2017; GIONCADA et al., 2018b). A similar scenario might be evoked for explaining the high degree of preservation shown by CPI-7937. Support of this interpretation comes from observing that the internal rostral ducts have collapsed, which implies that the rostral cartilage underwent diagenetic compaction before mineralisation could occur.

\section{Discussion and conclusions}

To our knowledge, the partial rostrum of Pristis $\mathrm{sp}$. described herein from the middle Eocene Paracas Formation represents the geologically oldest fossil record of Pristidae from the Pacific Coast of South America and, seemingly, from the whole Pacific realm (Fig. 5). Furthermore, it consists of an exceptionally well preserved specimen that allows for the observation of anatomical structures that are unlikely to leave a fossil record, e.g., the paracentral grooves that extend along the ventral surface of the rostrum and the individual tesserae that form the coat of prismatic cartilage surrounding the external surface of the rostrum. Therefore, our finding contributes to further qualify the sedimentary infill of the East Pisco Basin as a true Konservat-Lagerstätte, the outstanding fossil content of which is crucial for reconstructing the Cenozoic history of the cartilaginous fish faunas of Pacific South America (CARRILLO-BRICEÑo et al., 2018). Not least, the discovery of CPI-7937 promotes the quest for well-preserved fossil chondrichthyans over the entire stratigraphic succession exposed in the Ica Desert.

Nowadays, sawfishes are absent from the coastal waters of southern Peru. However, in the East Pisco Basin, pristids are known as fossils from the Miocene strata of both the Chilcatay and the Pisco formations (BIANUCCI et al., 2016b, 2018; LANDini et al., 2017a, 2017ba, 2019; DI Celma et al., 2018b, 2019; Bosio et al., 2020). Of all these Miocene occurrences, which consist of rostral spines only, those that can be confidently identified at the genus level are assigned to Anoxypristis (e.g., BianUcCI et al., 2018; Bosio et al., 2020). While extant Anoxypristis is confined to the Indo-western Pacific region, this genus had once a much wider distribution, largely overlapping that of Pristis, being indeed present in several Eocene to Pliocene sites of Africa, Asia, Europe, and North America (e.g., CAPPETTA, 2012, and references therein). The apparent replacement of Pristis by Anoxypristis recorded in the fossil record of the East Pisco Basin is thus difficult to 


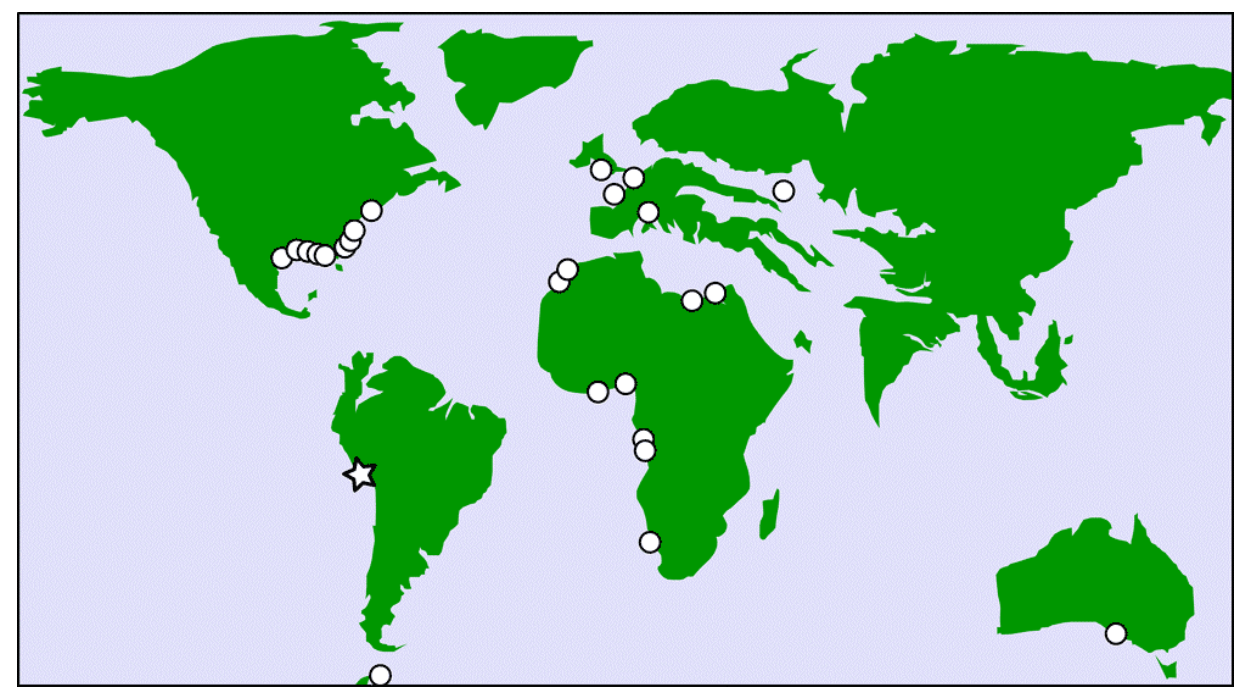

Figure 5: Schematic palaeogeographic distribution map of the Eocene fossils of Pristis (circles) based on the occurrences reported by CAPPETTA (2012) and The Paleobiology Database (available online at https://www. paleobiodb.org/). The star indicates the southern $\mathrm{Pe}$ ruvian site where CPI7937, the partial rostrum of Pristis sp. described herein, was found. Global palaeogeographic base map for the middle Eocene redrawn and modified after KošŤÁk et al. (2013: Fig. 10). interpret and might be due to collection biases. Further investigations on the understudied chondrichthyan assemblages of the Palaeogene deposits of the East Pisco Basin might contribute to shed light on this issue.

The living species of Anoxypristis and Pristis are shallow-water nectobenthic fish that occupy restricted habitats close inshore or even in freshwater, commonly in muddy enclosed bays, in estuaries, off river mouths, surrounding large continental islands, and upstream in rivers and lakes (COMPAGNO \& LAST, 1999). In particular, according to Allen (1982), Pristis spp. appear to prefer muddy substrates. These actualistic data are perfectly consistent with modern reconstructions of the bathymetric, physiographic, and sedimentological characteristics of the Yumaque depositional setting - an inshore, inner shelf palaeoenvironment, possibly connected with a series of semi-enclosed embayments, and characterised by a silty to silty-sandy seafloor (DUNBAR et al., 1990; UHEN et al., 2011).

In recent times, the palaeoclimatic significance of the Paracas Formation deposits has been the subject of some debate. UHEN et al. (2011) argued that the Paracas deposits represent a cool water depositional palaeoenvironment - a view that was previously proposed by DEVRIES et al. (2006). This hypothesis was based on $i$ ) the occurrence of some taxa of foraminifera (e.g., the genera Bolivina OrBIgNY, 1839, Nonion MONTFORT, 1808, and Uvigerina ORBIGNY, 1826) and nannoplankton [e.g., Coccolithus pelagicus (WALLICH, 1877)] that are currently associated with cool waters, and $i i)$ the frequent observation of loose scales of clupeoid fishes (i.e., anchovies and sardines), which correlates with relatively cool water environments in the Quaternary record of the Humboldt Current System off the Peruvian coast (UHEN et al., 2011, and references therein). However, a recent re-examination of the actualistic data about the micro- and nannofossil taxa from the Yumaque deposits revealed a somewhat weak correlation with cool waters (COLETTI et al., 2019), whereas the small-sized fish scales that are omnipresent in the same beds cannot be positively identified as belonging to any member of
Clupeoidea (personal observation by A.C.), a group of teleosts whose first unambiguous occurrence in the fossil record of the East Pisco Basin occurs in the upper Miocene strata of the Pisco Formation (COLLARETA et al., 2015; LAMBERT et al., 2015). Furthermore, considerations on the record of large benthic foraminifera from the Los Choros member, which includes abundant lepidocyclinids, as well as nummulitids and members of the extant genus Amphistegina ORBIGNY, 1826, provided a different interpretation of the Paracas depositional setting as a tropical palaeoenvironment (MoRALES-ReYNA et al., 2010, 2013; Coletti et al., 2019). As mentioned above, pristids are currently known as tropical/subtropical fishes (e.g., COMPAGNO \& LAST, 1999; WUERINGER et al., 2009; CAPPETTA, 2012; DuLVY et al., 2014); therefore, the present record of Pristis sp. from Zamaca further indicates that palaeoenvironmental conditions suitable for warm-water organisms characterised the East Pisco Basin during deposition of the $\mathrm{Pa}$ racas strata.

Although the large-tooth sawfish (Pristis pristis) might still inhabit tropical waters of northern Peru (Dulvy et al., 2014; MendozA et al., 2017), and the fossil record of pristids from the East Pisco Basin spans from the middle Eocene to the late Miocene, sawfishes are currently absent from the cool, upwelling-influenced coastal waters of present-day southern Peru - an observation that might suggest warmer-than-today seawater temperatures for the Lutetian nearshore environments of southern Peru. This interpretation fits perfectly the global climatic scenario of the middle Eocene, which was characterized by high temperatures worldwide (e.g., ZACHOs et al., 2001). Furthermore, it is consistent with previous reconstructions of the palaeoceanographic conditions of the coastal sea of southern Peru, which in Eocene times was likely characterized by a weaker-than-today upwelling system driven by a sort of "proto-Humboldt" current; the latter would have comprised the eastern arm of the relatively warm Southern Pacific gyre rather than representing a cooler byproduct of the circum-Antarctic circulation (MARTY et al., 1988). In this respect, it should be noted that the Lutetian records of 
Pristis spp. even include an occurrence from the Seymour Island, Antarctica (KRIWET, 2005), which suggests that the warm climate regime of the middle Eocene might have been reflected in a phase of remarkable range expansion towards the high latitudes for pristid sawfishes worldwide.

That said, what happened to the southeastern Pacific pristids, leading to their eventual extirpation from the southern Peruvian latitudes? Recent research (CARRILLO-BRICEÑo et al., 2018; PARTARRIEU et al., 2018; VillafañA \& Rivadeneira, 2018; VILLAFAÑA et al., 2019) has investigated the role of physiological, ecological, and life-history traits, as well as the influence of environmental and historical factors in controlling the diversity and distribution of Pacific South American chondrichthyans in Neogene and Quaternary times, but sawfishes have not been specifically addressed by these studies. Nonetheless, some answers could come from observing that another iconic tropical cartilaginous fish, the extinct snaggletooth shark Hemipristis serra AGASSIZ, 1843, is thought to have contracted its range northwards as cool conditions took hold along the coasts of southern Peru, during a middle or late Miocene phase of a stronger Humboldt Current (Bosio et al., 2020). Similarly, the horn shark Heterodontus BLAINVILLE, 1816, seems to have been extirpated from most of its southeastern Pacific grounds following a series of regional changes, including seawater cooling due to coastal upwelling and advection of Subantarctic water masses, during the Plio-Pleistocene (PARTARRIEU et al., 2018). A closer look at the habitat preferences of extant Pristis spp. could provide some further insights. Nowadays, pristids are regarded as highly imperilled fishes that are often associated with threatened seagrass meadows and mangrove forests (DULVY et al., 2014), some of which represent crucial nursery grounds for these highly idiosyncratic rays (SIMPFENDORFER, 2007). Present-day seagrasses are mostly known from tropical and subtropical environments; modern seagrass patches along the southeastern Pacific margin are limited to a few occurrences near Coquimbo, Chile (Kuo, 2005, and references therein), but meadows might have been more widespread along the western coastline of South America in the past (PHILlips et al., 1983). Mangrove forests are almost exclusively tropical habitats, their geographical spread being broadly delineated by the $20^{\circ} \mathrm{C}$ winter sea-temperature isotherm; in particular, South American Pacific mangroves are currently restricted to north of $5^{\circ} 32^{\prime} \mathrm{S}$ by the effect of the cold Humboldt Current (HogARTH, 2015). However, the presence of mangrove fringes in the East Pisco Basin during the lower Palaeogene has been hypothesised on the basis of the molluscan assemblage of the Cuenca Member of the Caballas Formation (DEVRIES, 2017, 2018), which stratigraphically underlies the Paracas strata (Dunbar et al., 1990; DeVRIES, 1998). Besides lowering coastal seawater temperatures to the discomfort of pristids, a Neogene phase of a stronger Humboldt Current would definitively have had a deleterious effect on mangroves and, possibly, on seagrasses as well, thus further compromising the fate of the South American Pacific sawfish communities via mechanisms of habitat loss and fragmentation. Therefore, in the light of the above considerations, the disappearance of pristids from the coastal waters off southern Peru could be interpreted as mainly reflecting the late Cenozoic trend of strengthening of the Humboldt Current, although the interplay of other environmental drivers (e.g., tectonoeustatic factors leading to the emersion of the East Pisco Basin and other semi-enclosed shelf areas) might also have had a significant role in causing the regional extirpation of sawfishes.

\section{Acknowledgments}

Our gratitude to William MARTínez-VALLADARES (Director of the Regional Geology Department, INGEMMET), for making available the facilities for carrying out this study. Thanks are also due to Rafael Martín VARAS-MALCA and Rodolfos SALASGismondi (both at Museo de Historia Natural de la Universidad Nacional Mayor de San Marcos) for their valuable assistance and fruitful discussion on several aspects of the marine vertebrate assemblages of the East Pisco Basin. We are also grateful to Claudio Di CeLmA (Università di Camerino) for his strong support during fieldwork in the East Pisco Basin. Constructive comments by Jürgen KRIWET (Institut für Paläontologie, Universität Wien), Frederik MOLLEN (Elasmobranch Research Belgium), and Jorge Domingo CARRILLOBRICEÑO (Paläontologisches Institut und Museum, Universität Zürich) greatly contributed to shape this work into its present form - we thank them for their support. Not least, thanks are due to Robert W. ScoTT (Precision Stratigraphy Associates), Bruno Granier (Université de Bretagne Occidentale), and Brian R. PRATT (University of Saskatchewan) for their valuable and thorough editorial support.

This research was supported by a grant by Università di Pisa to Giovanni BIANUCCI (PRA 2017_0032). The present paper is a contribution of the "Programa de Paleontología" of the Regional Geology Department, INGEMMET, and a result of the "Convenio Específico" between the INGEMMET and the Museo de Historia Natural de la Universidad Nacional Mayor de San Marcos.

\section{Bibliographic references}

AgAssiz L. (1843).- Recherches sur les poissons fossiles. Tome III (livr. 15-16).- Imprimerie de Petitpierre, Neuchâtel.

ALLEN G.R. (1982).- Inland fishes of Western Australia.- Western Australian Museum, Perth.

Bianucci G., Collareta A., Bosio G., Landini W., Gariboldi K., Gioncada A., Lambert O., MalinVerno E., Muizon C. de, Varas-Malca R.M., VilLA I.M, Coletti G., URBina-SChmitT M. \& Di CELMA C. (2018).- Taphonomy and palaeoecology of the lower Miocene marine vertebrate assemblage of Ullujaya (Chilcatay Formation, East Pisco Basin, southern Peru).- Palæogeography, Palæoclimatology, Palæoecology, vol. 
511, p. 256-279.

Bianucci G., Di Celma C., Collareta A., Landini W., Post K., Tinelli C., Muizon C. de, Bosio G., GARiboldi K., Gioncada A., Malinverno E., CantaLAMESSA G., ALtAMIRANO-SieRra A, SALAS-GisMONDI R., URBINA-SCHMITT M. \& LAMBERT O. (2016a).- Fossil marine vertebrates of Cerro Los Quesos: Distribution of cetaceans, seals, crocodiles, seabirds, sharks, and bony fish in a late Miocene locality of the Pisco Basin, Peru.Journal of Maps, vol. 12, no. 5, p. 1037-1046.

Bianucci G., Di Celma C., Landini W., Post K., Tinelli C., Muizon C. de, Gariboldi K., Malinverno E., Cantalamessa G., Gioncada A., Collareta A., SALAS-Gismondi R., VARAS-MALCA R.M., URBINA-SCHMITT M. \& LAMBERT O. (2016b).- Distribution of fossil marine vertebrates in Cerro Colorado, the type locality of the giant raptorial sperm whale Livyatan melvillei (Miocene, Pisco Formation, Peru).- Journal of Maps, vol. 12, no. 3, p. 543-557.

Bianucci G., LAMBert O. \& POSt K. (2010).- High concentration of long-snouted beaked whales (genus Messapicetus) from the Miocene of Peru.- Palaeontology, London, vol. 53, no. 5, p. 1077-1098.

BLAinVille H.M.D. de (1816).- Prodrome d'une nouvelle distribution systématique du règne animal.- Bulletin de la Société Philomathique de Paris, Paris, vol. 8, p. 105-112.

BONAPARTE C.L.J.L. (1838).- Selachorum tabula analytica.- Nuovi Annali delle Scienze Naturali, Bologna, vol. 1, no. 2, p. 195-214.

Bosio G., Malinverno E., Collareta A., Di Celma C., Gioncada A., Parente M., Berra F., MarX F.G., Vertino A., URbinA-Schmitt M. \& BianUCCI G. (2020).- Strontium Isotope Stratigraphy and the thermophilic fossil fauna from the middle Miocene of the East Pisco Basin (Peru).- Journal of South American Earth Sciences, Oxford, vol. 97, article \#102399.

BOURDON J. (1999).- The life and times of long dead sharks. Available from URL: http://www. elasmo.com/, accessed on August 16, 2019.

Brand L.R, Esperante R., ChadWick A.V., PomaPorras O., Alomia M. (2004).- Fossil whale preservation implies high diatom accumulation rate in the Miocene-Pliocene Pisco Formation of Peru.- Geology, Boulder, vol. 32, no. 2, p. 165-168.

CAPPETtA H. (1980).- Les sélaciens du Crétacé supérieur du Liban. II. Batoïdes.- Palaeontographica Abteilung A, Paläozoologie-Stratigraphie, Stuttgart, vol. 168, no. 5-6, p. 149-229.

CAPPETTA H. (2006).- Elasmobranchii Post-Triadici (Index generum et specierum). In: Reigraf W. (ed.), Fossilium Catalogus I: Animalia, Pars 142.- Backhuys Publishers, Leiden, p. 1-472.

CAPPETtA H. (2012).- Chondrichthyes. Mesozoic and Cenozoic Elasmobranchii. Teeth. In: SCHULTZE H.P. (ed.), Handbook of Paleoichthyology, vol. 3E.- Dr. Pfeil Verlag, Munich, p. $1-512$.

CAPPETTA H. \& CASE G.R. (2016).- A selachian fauna from the middle Eocene (Lutetian, Lisbon Formation) of Andalusia, Covington County,
Alabama, USA.- Palaeontographica Abteilung A, Paläozoologie, Stratigraphie, Stuttgart, vol. 307, no. 1-6, p. 43-103.

Carrillo-Briceño J.D., Carrillo J.D., Aguilera O.A. \& SANCHEZ-VilLAGRA M.R. (2018).- Shark and ray diversity in the Tropical America (Neotropics)-an examination of environmental and historical factors affecting diversity.- PeerJ, vol. 6, article \#e5313.

Carrillo-Briceño J.D., LuZ Z., Hendy A., Kocsis L., Aguilera O. \& Vennemann T. (2019).- Neogene Caribbean elasmobranchs: diversity, paleoecology and paleoenvironmental significance of the Cocinetas Basin assemblage (Guajira Peninsula, Colombia).- Biogeosciences, vol. 16, no. 1, p. 33-56.

Carrillo-Briceño J.D., MaxWell E., Aguilera O.A., SÁNCHEZ R. \& SÁNCHEZ-VilLAGRA M.R. (2015).Sawfishes and other elasmobranch assemblages from the Mio-Pliocene of the South Caribbean (Urumaco sequence, northwestern Venezuela).- PLOS ONE, vol. 10, article \# 0139230.

CASE G.R. (1994).- Fossil fish remains from the Late Paleocene Tuscahoma and Early Eocene Bashi formations of Meridian, Lauderdale County, Mississippi. Part I. Selachians.- Palaeontographica Abteilung A, PaläozoologieStratigraphie, Stuttgart, vol. 230, p. 97-138

CASIER E. (1949).- Contributions à l'étude des poissons fossiles de la Belgique. VIII. Les Pristidés éocènes.- Bulletin de l'Institut royal des Sciences Naturelles de Belgique, Bruxelles, vol. 25, no. 10, p. 1-52.

CiCIMURRI D.J. (2007).- A partial rostrum of the sawfish Pristis lathami GALEOTTI, 1837, from the Eocene of South Carolina.- Journal of Paleontology, Lawrence, vol. 81, no. 3, p. 597601.

Clarke J.A., Ksepka D.T., Salas-Gismondi R., AltaMIRANO-SierRA A.J., ShaWKey M.D., D'Alba L., Vinther J., DeVRIES T.J. \& BABY P. (2010).Fossil evidence for evolution of the shape and color of penguin feathers.- Science, Washington D.C., vol. 330, no. 6006, p. 954-957.

Clarke J.A., Ksepka D.T., StUCChi M., URBinASchmitt M., Giannini N., Bertelli S., Narváez Y. \& BOYD C.A. (2007).- Paleogene equatorial penguins challenge the proposed relationship between biogeography, diversity, and Cenozoic climate change.- Proceedings of the $\mathrm{Na}$ tional Academy of Sciences, Washington D.C., vol. 104, no. 28, p. 11545-11550.

Coletti G., Bosio G., Collareta A., Buckeridge J., Consani S. \& El Kateb A. (2018).- Palaeoenvironmental analysis of the Miocene barnacle facies: case studies from Europe and South America.- Geologica Carpathica, Bratislava, vol. 69, no. 6, p. 573-592.

Coletti G., Bosio G., Collareta A., Malinverno E., Bracchi V., Di Celma C., Basso D., Stainbank S., Spezzaferri S., Cannings T. \& Bianucci G. (2019).- Biostratigraphic, evolutionary, and paleoenvironmental significance of the southernmost lepidocyclinids of the Pacific coast of South America (East Pisco Basin, southern Peru).- Journal of South American Earth 
Sciences, Oxford, vol. 96, article \#102372.

Collareta A., Casati S. \& Di Cencio A. (2017a).- A pristid sawfish from the lower Pliocene of Lucciolabella (Radicofani basin, Tuscany, central Italy).- Atti della Società Toscana di Scienze Naturali, Memorie, Serie A, Pisa, vol. 124, no. 3, p. 49-55.

Collareta A., Casati S., Catanzariti R. \& Di Cencio A. (2017b).- First record of the knifetooth sawfish Anoxypristis (Elasmobranchii: Rhinopristiformes) from the Pliocene of Tuscany (central Italy).- Neues Jahrbuch für Geologie und Paläontologie-Abhandlungen, Stuttgart, vol. 284 , p. 289-297.

Collareta A., Landini W., Chacaltana-Budiel C., Valdivia-Vera W., Altamirano-Sierra A., URBINA-SCHMITT M. \& BiANUCCI G. (2017c).- A well preserved skeleton of the fossil shark Cosmopolitodus hastalis from the late Miocene of Peru, featuring fish remains as fossilized stomach contents.- Rivista Italiana di Paleontologia e Stratigrafia (Research in Paleontology and Stratigraphy), Milan, vol. 123, no. 1, p. 11-22.

Collareta A., Landini W., Lambert O., Post K., Tinelli C., Di Celma C., Panetta D., Tripodi M., Salvadori P.A., Caramella D., Marchi D., URBINA-SCHMITT M. \& BIANUCCI G. (2015).- Piscivory in a Miocene Cetotheriidae of Peru: first record of fossilized stomach content for an extinct baleen-bearing whale.- The Science of Nature (Naturwissenschaften), Berlin-Heidelberg, vol. 102, no. 11-12, article \#70.

Compagno L.J.V. (1977).- Phyletic relationships of living sharks and rays.- American Zoologist, Lawrence, vol. 17, p. 303-322.

COMPAGNo L.J.V. \& LAST P.R. (1999).- Order Pristiformes. Pristidae. Sawfishes. In: CARPENTER K.E. \& NIEM V.H. (eds.), FAO Species Identification Guide for Fisheries Purposes. The Living Marine Resources of the Western Central Pacific. Volume 3. Batoid fishes, chimaeras and bony fishes. Part 1 (Elopidae to Linophrynidae).- FAO, Rome, p. 1410-1417.

DÁvilA D. (1989).- Estratigrafía Cenozoica del valle del Río Grande, Cuenca de Pisco - Perú.Boletín de la Sociedad Geológica del Perú, Lima, vol. 80, p. 65-76.

DEVRIES T.J. (1998).- Oligocene deposition and Cenozoic sequence boundaries in the Pisco Basin (Peru).- Journal of South American Earth Sciences, Oxford, vol. 11, no. 3, p. 217-231.

DEVRIES T.J. (2017).- Eocene stratigraphy and depositional history near Puerto Caballas (East Pisco Basin, Peru).- Boletín de la Sociedad Geológica del Perú, Lima, vol. 112, p. 39-52.

DeVRIES T.J. (2018).- Early Paleogene brackishwater molluscs from the Caballas Formation of the East Pisco Basin (Southern Peru).- Journal of Natural History, London, vol. 53, no. 25-26, p. 1-52.

DeVRIES T.J. \& JUD N.A. (2018).- Lithofacies patterns and paleogeography of the Miocene Chilcatay and lower Pisco depositional sequences (East Pisco Basin, Peru).- Boletín de la Sociedad Geológica del Perú, Lima, vol. jubilar 8, p.
124-167.

DeVries T.J., Navarez Y., Sanfilippo A., Malumian N. \& TAPIA P. (2006).- New microfossil evidence for a late Eocene age of the Otuma Formation (Southern Peru). In: XVIII Congreso Peruano de Geología, Resúmenes extendidos (Actas).- Sociedad Geológica del Perú, Lima.

di Celma C., Malinverno E., Bosio G., Collareta A., Gariboldi K., Gioncada A., Molli G., Basso D., Varas-Malca R.M., Pierantoni P.P., Villa I.M., Lambert O., Landini W., Sarti G., CantalaMESSA G., URBINA-SCHMITT M. \& BIANUCCI G. (2017).- Sequence stratigraphy and paleontology of the upper Miocene Pisco Formation along the western side of the lower Ica valley (Ica Desert, Peru).- Rivista Italiana di Paleontologia e Stratigrafia (Research in Paleontology and Stratigraphy), Milan, vol. 123, no. 2, p. 255-274.

di Celma C., Malinverno E., Bosio G., Gariboldi K., Collareta A., Gioncada A., Landini W., PieRANTONI P.P., BIANUCCI G. (2018b).- Intraformational unconformities as a record of late Miocene eustatic falls of sea level in the Pisco Formation (southern Peru). Journal of Maps, vol. 14 , no. 2 , p. 607-619.

Di Celma C., Malinverno E., Cantalamessa G., Gioncada A., Bosio G., Villa I.M., Gariboldi K., Rustichelli A., Pierantoni P.P., Landini W., Tinelli C., Collareta A. \& Bianucci G. (2016).Stratigraphic framework of the late Miocene Pisco Formation at Cerro Los Quesos (Ica Desert, Peru). Journal of Maps, vol. 12, no.5, p. 1020-1028.

di Celma C., Malinverno E., Collareta A., Bosio G., Gariboldi K., Lambert O., Landini W., PieRANTONi P.P., Gioncada A., Villa I.M., Coletti G., Muizon C. de, URBina-Schmitt M. \& Bianucci G. (2018a).- Facies analysis, stratigraphy and marine vertebrate assemblage of the lower Miocene Chilcatay Formation at Ullujaya (Pisco basin, Peru).- Journal of Maps, vol. 14, no. 2, p. 257-268.

Di Celma C., Pierantoni P.P., Malinverno E., CollaReta A., LAMbert O., LANDini W., Bosio G., GaRiboldi K., Gioncada A., Muizon C. de, Molli G., MARX F.G., VARAS-MALCA R.M., URBinASCHMITT M. \& BiAnUCCI G. (2019).- Allostratigraphy and paleontology of the lower Miocene Chilcatay Formation in the Zamaca area, East Pisco basin, southern Peru.- Journal of Maps, vol. 15, no. 2, p. 393-405.

DuCARME F., LUQUE G.M. \& COURCHAMP F. (2013).What are "charismatic species" for conservation biologists?- BioSciences Master Reviews, Lyon, vol. 2013 (July), p. 1-8.

DULVY N.K., DAVIDSON L.N., KYNE P.M., SimpFENDORFER C.A., HARRISON L.R., CARLSON J.K. \& FORDHAM S.V. (2014).- Ghosts of the coast: global extinction risk and conservation of sawfishes.Aquatic Conservation: Marine and Freshwater Ecosystems, London, vol. 26, no. 1, p. 134153.

DUNBAR R.B., MARTY R.C. \& BAKER P.A. (1990).Cenozoic marine sedimentation in the Sechura and Pisco basins, Peru.- Palæogeography, Pa- 
læoclimatology, Palæoecology, vol. 77, no. 34, p. 235-261.

Esperante R., BRAND L.R., ChadWick A.V. \& PomaPorras O. (2015).- Taphonomy and paleoenvironmental conditions of deposition of fossil whales in the diatomaceous sediments of the Miocene/Pliocene Pisco Formation, southern Peru - a new Fossil-Lagerstätte.- Palæogeography, Palæoclimatology, Palæoecology, vol. 417, p. 337-370.

Esperante R., Brand L.R., Nick K.E., Poma-Porras O. \& URBINA-SCHMITT M. (2008).- Exceptional occurrence of fossil baleen in shallow marine sediments of the Neogene Pisco Formation, Southern Peru.- Palæogeography, Palæoclimatology, Palæoecology, vol. 257, no. 3, p. 344360.

Faria V.V., McDavitT M.T., Charvet P., Wiley T.R., SimpFENDORFER C.A. \& NAYLOR G.J.P. (2013).Species delineation and global population structure of critically endangered sawfishes (Pristidae).- Zoological Journal of the Linnean Society, London, vol. 167, no. 1, p. 136-164.

FARRÉS F. (2003).- Mesopristis nov. gen. osonensis nov. sp., nuevo género y especie de piezsierra del Eoceno de Vic, (Catalunya, NE. de España). - Batalleria, Barcelona, vol. 11, p. 93-113.

GALEOTTI H. (1837).- Mémoire sur la constitution géognostique de la Brabant. Mémoires de l'Académie des Sciences de la Belgique, 4, Bruxelles, vol. 12, no. 3, p. 1-193.

Gariboldi K., Gioncada A., Bosio G., Malinverno E., Di Celma C., Tinelli C., Cantalamessa G., LANDINI W., URBINA-SCHMITT M. \& BiANUCCI G. (2015).- The dolomite nodules enclosing fossil marine vertebrates in the East Pisco Basin, Peru: field and petrographic insights into the Lagerstätte formation.- Palæogeography, Palæoclimatology, Palæoecology, vol. 438, p. 81-95.

GARMAN S. (1906).- New Plagiostoma.- Bulletin of the Museum of Comparative Zoology at Harvard College, Cambridge (Mass.), vol. 46, no. 11 , p. 203-208

Gioncada A., Collareta A., Gariboldi K., Lambert O., Di Celma C., Bonaccorsi E., URBinA-Schmitt M. \& BiAnUCCI G. (2016).- Inside baleen: exceptional microstructure preservation in a late Miocene whale skeleton from Peru.- Geology, Boulder, vol. 44, no. 10, p. 839-842.

Gioncada A., Gariboldi K., Collareta A., Di Celma C., Bosio G., Malinverno E., Lambert O., Pike J., URBina-SChmitt M. \& BiAnUCCI G. (2018a).Looking for the key to preservation of fossil marine vertebrates in the Pisco Formation of Peru: new insights from a small dolphin skeleton.- Andean Geology, Santiago, vol. 45, no. 3, p. 379-398.

Gioncada A., Petrini R., Bosio G., Gariboldi K., Collareta A., Malinverno E., Bonaccorsi E., Di Celma C., Pasero M., Urbina-Schmitt M. \& BiaNUCCI G. (2018b).- Insights into the diagenetic environment of fossil marine vertebrates of the Pisco Formation (late Miocene, Peru) from mineralogical and Sr-isotope data.- Journal of South American Earth Sciences, Oxford, vol.
81 , p. $141-152$

Hampel A., Kukowski N., Bialas J., Heubscher C. \& HeinboCKEL R. (2004).- Ridge subduction at an erosive margin: the collision zone of the Nazca Ridge in southern Peru.- Journal of Geophysical Research, Lawrence, vol. 109, no.B2, article \#B02101.

Herman J., Hovestadt-Euler M., Hovestadt D.C. \& Stehmann M. (1997).- Part B: Batomorphii No. 2: Order Raijformes - Suborder: Pristoidei Family: Pristidae - Genera: Anoxypristis and Pristis No. 3: Suborder Rajoidei - Superfamily Rhinobatoidea -Families: Rhinidae - Genera: Rhina and Rhynchobatus and Rhinobatidae Genera: Aptychotrema, Platyrhina, Platyrhinoidis, Rhinobatos, Trygonorrhina, Zanobatus and Zapteryx. In: SteHMANN M. (ed.), Contributions to the study of the comparative morphology of teeth and other relevant ichthyodorulites in living supra-specific taxa of Chondrichthyan fishes. - Bulletin de I'Institut Royal des Sciences Naturelles de Belgique - Biologie, Bruxelles, vol. 67, p. 107-162.

HogARTH P.J. (2015).- The biology of mangroves and seagrasses. $3^{\text {rd }}$ Edition.- Oxford University Press, Oxford.

Hsu J.T. (1992).- Quaternary uplift of the Peruvian coast related to the subduction of the Nazca Ridge: 13.5 to 15.6 degrees South latitude.- Quaternary International, London, vol. 15-16, p. 87-97.

HUXLEY T.H. (1880).- On the application of the laws of evolution to the arrangement of the Vertebrata, and more particularly of the Mammalia.- Proceedings of the Zoological Society of London, London, vol. 1880, p. 649-662.

KošŤÁK M., JAGT J.W., SPEIJeR R.P., StASSEN P. \& Steurbaut E. (2013).- New Paleocene sepiid coleoids (Cephalopoda) from Egypt: evolutionary significance and origin of the sepiid 'rostrum'.- PLOS ONE, vol. 8, article \#e81180.

KRIWET J. (2005).- Additions to the Eocene selachian fauna of Antarctica with comments on Antarctic selachian diversity.- Journal of Vertebrate Paleontology, Lawrence, vol. 25, no. 1, p. 1-7.

Kuo J. (2005).- A revision of the genus Heterozostera (Zosteraceae).- Aquatic Botany, Cambridge, vol. 81, no. 2, p. 97-140.

LAMBert O., BianuCCI G., POSt K., Muizon C. de, SALAS-Gismondi R., URBina-Schmitt M. \& Reumer J. (2010).- The giant bite of a new raptorial sperm whale from the Miocene epoch of Peru.Nature, London, vol. 466, p. 105-108.

LAMBERT O., BianuCCI G., SALAS-GiSmONDI R., Di Celma C., Steurbaut E., URbina-Schmitt M. \& Muizon C. de (2019).- An amphibious whale from the middle Eocene of Peru reveals early South Pacific dispersal of quadrupedal cetaceans.- Current Biology, London, vol. 29, no. 8, p. 1352-1359.

Lambert O., Collareta A., Landini W., Post K., Ramassamy B., Di Celma C., URBina-Schmitt M. \& BIANUCCI G. (2015).- No deep diving: evidence of predation on epipelagic fish for a stem beaked whale from the Late Miocene of Peru.- 
Proceedings of the Royal Society B: Biological Sciences, London, vol. 282, no. 1815, article\# 20151530.

Lambert O., Martínez-Cáceres M., Bianucci G., Di Celma C., Salas-Gismondi R., Steurbaut E., URBINA-SCHMITT M. \& MuIZON C. de (2017).- Earliest mysticete from the Late Eocene of Peru sheds new light on the origin of baleen whales.- Current Biology, London, vol. 27, no. 10, p. 1535-1541.

Landini W., Altamirano-Sierra A., Collareta A., Di Celma C., URbina-Schmitt M. \& Bianucci G. (2017a).- The late Miocene elasmobranch assemblage from Cerro Colorado (Pisco Formation, Peru). Journal of South American Earth Sciences, Oxford, vol. 73, p. 168-190.

Landini W., Collareta A., Pesci F., Di Celma C., URBINA-SChmitT M., BiAnUCCI G. (2017b).- A secondary nursery area for the copper shark Carcharhinus brachyurus from the late Miocene of Peru.- Journal of South American Earth Sciences, Oxford, vol. 78, p. 164-174.

landini W., Collareta A., Di Celma C., Malinverno E., URbina-Schmitt M. \& Bianucci G. (2019).The early Miocene elasmobranch assemblage from Zamaca (Chilcatay Formation, Peru).Journal of South American Earth Sciences, Oxford, vol. 91, p. 352-371.

LANGE T, BREHM J. \& MORITZ T. (2015).- A practical key for the identification of large fish rostra.Spixiana, München, vol. 38, no. 1, 145-160.

LAST P.R., White W.T., CaRvalho M.R. de, SÉret B., SteHMANN M.F.W. \& NAYLOR G.J.P. (2016).Rays of the World.- CSIRO Publishing, Melbourne.

LATHAM J. (1794).- An essay on the various species of Sawfish.- Transactions of the Linnean Society of London, London, vol. 2, p. 273-282.

león W., Aleman A., Torres V., Rosell W. \& Cruz O. de la (2008).- Estratigrafía, sedimentología y evolución tectónica de la cuenca Pisco Oriental.- Boletín INGEMMET, Lima, ser. D., vol. 27, p. 144

LERICHE M. (1905).- Les poissons Éocènes de la Belgique.- Mémoires du Musée Royal d'Histoire Naturelle de Belgique, Bruxelles, vol. 3, no. 3, p. 49-228.

LINCK H.F. (1790).- Versuch einer Eintheilung der Fische nach den Zähnen.- Magazin für das Neueste aus der Physik und Naturgeschichte, Gotha, vol. 6, no. 3, p. 28-38.

LinNAEUS C. (1758).- Systema Naturae. Editio decima, reformata. Tomus I.- L. Salvius, Stockholm.

MACHARÉ J. \& ORTLIEB L. (1992).- Plio-Quaternary vertical motions and the subduction of the Nazca Ridge, central coast of Peru.- Tectonophysics, vol. 205, no. 1-3, p. 97-108.

MARSILI S. (2006).- Analisi sistematica, paleoecologica e paleobiogeografica della selaciofauna Plio-Pleistocenica del Mediterraneo.- Ph.D. Thesis, Università di Pisa, Pisa.

MARTY R., DUNBAR R., MARTIN J.B. \& BAKER P. (1988).- Late Eocene diatomite from the Peruvian coastal desert, coastal upwelling in the eastern Pacific, and Pacific circulation before the terminal Eocene event.- Geology, Boulder, vol. 16, no. 9, p. 818-822.

Marx F.G., Collareta A., Gioncada A., Post K., LAMBERT O., BONACCORSI E., URBINA-SCHMITT M. \& BIANUCCI G. (2017).- How whales used to filter: exceptionally preserved baleen in a Miocene cetotheriid.- Journal of Anatomy, London, vol. 231 , no. 2, p. 212-220.

Mendoza A., Kelez S., Cherres W.G. \& Maguiño R. (2017).- The Largetooth Sawfish, Pristis pristis (LINNAEUS, 1758), is not extirpated from Peru: new records from Tumbes.- Check List, vol. 13 , p. 261-265.

MilleR W.A. (1974).- Observations on the developing rostrum and rostral teeth of sawfish: Pristis perotteti and P. cuspidatus.- Copeia, Lawrence, 1974 , no. 2, p. 311-318.

MONTFORT P.D. de (1808).- Conchyliologie systématique et classification méthodique des coquilles. Vol. 1.- Schoell, Paris.

Morales-Reyna M.C., Chacaltana-Budiel C. \& ValDIVIA-VERA W. (2010).- Lepidocyclina (Lepidocyclina) peruviana (CUSHMAN) en la Cuenca Pisco: geocronologia y paleoambiente.- Sociedad Geológica del Perú, Special Publication, Lima, vol. 9, p. 237-240.

Morales-Reyna M.C., Tejada-Medina L., ChacaltaNA-BUdiEL C. (2013).- Significado de la presencia del foraminifero Amphistegina sp. del Paleógeno en la cuenca Pisco. In: I Simposio Internacional de Paleontologia del Perú, Libro de Resúmenes.- INGEMMET, Lima, p. 29-31.

Muizon C. de (1988).- Les vertébrés de la Formation Pisco (Pérou). Troisième partie: Les odontocètes (Cetacea, Mammalia) du Miocène.Travaux de l'Institut Français d'Études Andines, Lima, vol. 42, no. 3, p. 1-244.

Muizon C. de \& DeVRIES T.J. (1985).- Geology and paleontology of late Cenozoic marine deposits in the Sacaco area (Peru).- Geologische Rundschau, vol. 74, p. 547-563.

MülleR J. \& HenLE J. (1841).- Systematische Beschreibung der Plagiostomen.- Von Veit, Berlin.

NACSN [North American Commission on Stratigraphic Nomenclature] (2005).- North American stratigraphic code.- American Association of Petroleum Geologists Bulletin, Tulsa, vol. 89, p. 1547-1591.

NAYLOR G.J.P., CAIRA J.N., JENSEN K., ROSANA K.A.M., Straube N. \& LaKner C. (2012).- Elasmobranch phylogeny: A mitochondrial estimate based on 595 species. In: CARrier J.C., MuSick J.A. \& Heithaus M.R. (eds.), Biology of sharks and rays and their relatives.- CRC Press, Boca Raton, p. 31-57.

Nevatte R.J., Wueringer B.E., JAcob D.E., PARK J.M. \& Williamson J.E. (2017).- First insights into the function of the sawshark rostrum through examination of rostral tooth microwear.- Journal of Fish Biology, London, vol. 91 , no. 6, p. 1582-1602.

OrBigny, A.D. d' (1826).- Tableau méthodique de la classe des Céphalopodes.- Annales des Sciences Naturelles, Paris, vol. 7, no. 7, p. 96$169,245-314$ 
OrbignY, A.D. d' (1839).- Foraminifères. In: SAGRA R. de la, Histoire Physique, Politique et Naturelle de l'île de Cuba.- A. Bertrand, Paris, p. 1-224.

Partarrieu D., Villafaña J.A., Pinto L., Mourgues F.A., Oyanadel-Urbina P.A., Rivadeneira M.M. \& CARRILlO-BRICEÑO J.D. (2018).- Neogene 'horn sharks' Heterodontus (Chondrichthyes: Elasmobranchii) from the Southeastern Pacific and their paleoenvironmental significance.- Ameghiniana, Buenos Aires, vol. 55, no. 6, p. 651667.

Phillips R.C., Santelices B., BRavo R. \& McRoy C.P. (1983).- Heterozostera tasmanica (MARTENS ex Aschers.) den Hartog in Chile.- Aquatic Botany, Cambridge, vol. 15, no. 2, 195200.

PILGER R.H. (1981).- Plate reconstructions, aseismic ridges, and low-angle subduction beneath the Andes.- Geological Society of America Bulletin, Boulder, vol. 92, p. 448-456.

RIVERA R. (1957).- Moluscos fosiles de la Formacion Paracas, dpto. de Ica.- Boletín de la Sociedad Geológica del Perú, Lima, vol. 32, p. $165-219$.

SeITZ J.C. \& Hoover J.J. (2017).- Taxonomic resolution of sawfish rostra from two private collections.- Endangered Species Research, 32, 525-532.

Shimada K., Chandler R.E., LAM O.L.T., TANAKA T. \& WARD D.J. (2017).- A new elusive otodontid shark (Lamniformes: Otodontidae) from the lower Miocene, and comments on the taxonomy of otodontid genera, including the 'megatoothed' clade.- Historical Biology, London, vol. 29, no. 5, p. 704-714.

SIMPFENDORFER C.A. (2007).- The importance of mangroves as nursery habitat for smalltooth sawfish (Pristis pectinata) in South Florida.Bulletin of Marine Science, Miami, vol. 80, no. 3, p. 933-934.

Tsuchi R., Shuto T., TAKayama T., Fujiyoshi A., KoIzUmi I., Ibaraki M., Rangel Z.C. \& AldanA A.M. (1988).- Fundamental data on Cenozoic biostratigraphy of the Pacific coast of Peru. In: Tsuchi R. (ed.), Reports of Andean Studies, Special Volume 2. Shizuoka University, Shizuoka, p. 45-70.

Uhen M.D., Pyenson N.D., DeVRies T.J., URbinASchmitt M., RenNe P.R. (2011).- New middle Eocene whales from the Pisco Basin of Peru.Journal of Paleontology, Lawrence, vol. 85, p. 955-969.

Vigliarolo G. (1891).- Monografia dei Pristis fossili con la descrizione di una nuova specie nel calcare miocenico di Lecce.- Atti della Reale Accademia delle Scienze Fisiche e Matematiche di Napoli, Napoli, ser. 2, vol. 4, app. 3, p.
$1-28$.

Villafaña J.A. \& Rivadeneira M.M. (2018).- The modulating role of traits on the biogeographic dynamics of chondrichthyans from the Neogene to the present.- Paleobiology, Lawrence, vol. 44, no. 2, p. 251-262.

Villafaña J.A., Nielsen S.N., Klug S. \& Kriwet J. (2019).- Early Miocene cartilaginous fishes (Chondrichthyes: Holocephali, Elasmobranchii) from Chile: diversity and palaeobiogeographic implications.- Journal of South American Earth Sciences, Oxford, vol. 96, article \#102317.

WALLICH G.C. (1877).- Observations on the coccosphere.- Annals and Magazine of Natural History, London, ser. 4, vol. 19, no. 34, p. 342-350.

Weigmann S. (2016).- Annotated checklist of the living sharks, batoids and chimaeras (Chondrichthyes) of the world, with a focus on biogeographical diversity.- Journal of Fish Biology, London, vol. 88, no. 3, p. 837-1037.

Welten M., SMith M.M., UNDERWOOd C. \& Johanson Z. (2015).- Evolutionary origins and development of saw-teeth on the sawfish and sawshark rostrum (Elasmobranchii; Chondrichthyes).- Royal Society Open Science, vol. 2, article \#150189.

White E.I., Moy-Thomas J.A. (1941).- Notes on the nomenclature of fossil fishes. Part III. Homonyms M-Z. Annals and Magazine of Natural History, Series 11, London, ser. 11, no. 25, vol. 7, p. 395-400.

WhitTY J.M., Phillips N.M., ThORBURN D.C., Simpfendorfer C.A., Field I., Peverell S.C. \& MorGAN D.L. (2014).- Utility of rostra in the identification of Australian sawfishes (Chondrichthyes: Pristidae).- Aquatic Conservation: Marine and Freshwater Ecosystems, London, vol. 24, no. 6, p. 791-804.

Wueringer B.E., Peverell S.C., Seymour J., SQuire Jr L., KaJiuRA S.M. \& Collin S.P. (2011).- Sensory systems in sawfishes. 1. The ampullae of LoRENZINI.- Brain, Behavior and Evolution, Basel, vol. 78, no. 2, p. 139-149.

WUERINGER B.E., SQUiRE Jr L. \& Collin S.P. (2009).- The biology of extinct and extant sawfish (Batoidea: Sclerorhynchidae and Pristidae).- Reviews in Fish Biology and Fisheries, London, vol. 19, p. 445-464.

Zachos J., Pagani M., SloAN L., Thomas E. \& BilLUPS K. (2001).- Trends, Rhythms, and Aberrations in Global Climate $65 \mathrm{Ma}$ to Present.Science, Washington D.C., vol. 292, no. 5517, p. 686-693.

ZBYSZEWSKI G. (1947).- Découverte d'un rostre de grand Pristis dans I'Helvétien de Lisbonne.Boletim da Sociedade Geológica de Portugal, Lisbon, vol. 6, p. 236-242. 